\title{
EXPLOITATION OF EM.1-TREATED BLEND OF ORGANIC RESOURCES AND HUMIC ACID FOR ORGANIC BERSEEM (Trifolium alexandrinum L.) PRODUCTION
}

\author{
Ihsanullah DAUR*, Awad Osman ABUSUWAR, Fahad ALGHABARI \\ King Abdulaziz University, Faculty of Meteorology, Department of Arid Land Agriculture, \\ Environment \& Arid Land Agriculture, Jeddah, Saudi Arabia \\ *Corresponding author: iaslam@kau.edu.sa
}

Received: 26.03.2015

\begin{abstract}
A field trial was conducted to evaluate blends of organic resources and humic acids, in order to enhance organic berseem forage production. The objective of this study was to compare an EM.1 (effective microorganisms)-treated blend of organic resources with an untreated blend of organic resources, and thereby evaluate the usefulness of humic acid as an organic fertilizer. The two types of blends,each with 4 application levels $\left(0,15,30\right.$, and $\left.45 \mathrm{t} \cdot \mathrm{ha}^{-1}\right)$, and humic acid $\left(4\right.$ application levels: $0,15,30$, and $\left.45 \mathrm{~kg} \cdot \mathrm{ha}^{-1}\right)$ were evaluated using a randomized complete block design with a split-plot arrangement (blend types were the main plot factor and humic acid a sub-plot factor). Except for the difference in EM.1 inoculation, both blends were prepared by co-composting cow manure, poultry manure, and kitchen waste (2:1:1 ratio by volume, respectively).

The differences among treatments with respect to fresh and dry yield, as well as mineral composition were recorded. The blend treated with effective microorganisms was found to be a more effective fertilizer than the untreated blend. Additionally, heavier application of both types of organic resource blends and humic acid enhanced both fresh and dry yields, and improved the mineral composition of the crop. These findings are valuable for organic growers and it may open a new avenue for researchers worldwide.
\end{abstract}

Key words: Effective microorganisms, Organic fertilizers, Composting, Mineral composition

\section{INTRODUCTION}

Organic farming practices are rapidly becoming more popular globally, because the chemicals used in conventional agricultural systems have led to increasing concerns about food quality, sustainability, and other environmental consequences. Conversely, organic agriculture holds promise for the production of highquality food, increased sustainability, and better environmental protection (Gomiero et al., 2011). Because of the growing demand for organic dairy products from consumers in Saudi Arabia and many other parts of the world, farmers and agricultural companies are looking for a method of sustainable organic feed production. The most challenging difficulty for producers attempting to meet this demand is the lack of an appropriate organic fertilization plan, as the organic fertility plans suitable elsewhere, such as cover cropping and crop rotation, are not universally suitable. For example, in Saudi Arabia,it is not possible to grow more than a single crop per year, and organic fertilizers such as fish meal and bone meal are costly and not readily available. In Saudi Arabia and many other parts of the world, cow manure (CM), poultry manure (PM), and kitchen waste (KW) compost seems to be a good alternative choice for organic fertility management, because CM and PM are by-products of most farms, and $\mathrm{KW}$ is a waste product that is generally collected and piled outside cities as municipal solid waste. Furthermore, HA as an alternative source of organic amendment is compact, easy to ship, readily available, and its producers claim that $1 \mathrm{~kg}$ of $\mathrm{HA}$ provides as much fertilization benefit as 1 ton of manure (Humintech, 2012).

In this study, we treated plants with a blend of organic resources (BOR) and EM.1 (a group of coexisting microorganisms including lactic acid bacteria, yeast, and phototrophic bacteria) that is produced by EMRO (http://www.emrojapan.com), and is used for waste degradation and fermentation. The objective of this study was to increase the quantity and value of local organic fertilizer resources, because organic fertilizers are bulky and difficult to import. In accordance with the project's objectives, an attempt was made to utilize $\mathrm{KW}$ as some ratio of the $\mathrm{BOR}$, because it is generally discarded as waste in Saudi Arabia. The BOR was treated with EM.1 to increasing its fertilizing potential. Additionally, this study explored the use of HA as an organic fertilizer, a purpose for which it is not generally used. 


\section{MATERIALS AND METHODS}

Site and treatment of the experiment

A field trial was conducted from 2013 to 15 at the agriculture research station of King Abdulaziz University in the Hada-A'Sham area of Jeddah. In each growing season, a new section of the study field with the soil initial properties shown in Table 1 was used. Climatic conditions of the experimental site are shown in Fig. 1.

Table 1. Soil properties $(0-30 \mathrm{~cm})$ of the experimental site

\begin{tabular}{lcc}
\hline Soil properties $(\mathbf{0}-\mathbf{3 0} \mathbf{~ c m})$ & $\mathbf{2 0 1 3}$ & $\mathbf{2 0 1 4}$ \\
\hline $\mathrm{pH}$ & 7.8 & 7.7 \\
$\mathrm{EC}\left(\mathrm{dS} \cdot \mathrm{m}^{-1}\right)$ & 2.2 & 2.3 \\
Soil texture & Sandy Loam & Sandy Loam \\
Organic matter $(\%)$ & 0.65 & 0.66 \\
$\mathrm{~N}(\%)$ & 0.09 & 0.10 \\
$\mathrm{P}\left(\mathrm{mg} \cdot \mathrm{kg}^{-1}\right)$ & 124 & 140 \\
$\mathrm{~K}\left(\mathrm{mg} \cdot \mathrm{kg}^{-1}\right)$ & 184 & 178 \\
$\mathrm{Ca}\left(\mathrm{mg} \cdot \mathrm{kg}^{-1}\right)$ & 3108 & 3111 \\
$\mathrm{Mg}\left(\mathrm{mg} \cdot \mathrm{kg}^{-1}\right)$ & 121 & 144 \\
$\mathrm{Fe}\left(\mathrm{mg} \cdot \mathrm{kg}^{-1}\right)$ & 64.0 & 62.2 \\
$\mathrm{Cu}\left(\mathrm{mg} \cdot \mathrm{kg}^{-1}\right)$ & 1.20 & 1.55 \\
$\mathrm{Zn}\left(\mathrm{mg} \cdot \mathrm{kg}^{-1}\right)$ & 2.16 & 2.28 \\
$\mathrm{Mn}\left(\mathrm{mg} \cdot \mathrm{kg}^{-1}\right)$ & 6.98 & 7.55 \\
\hline
\end{tabular}

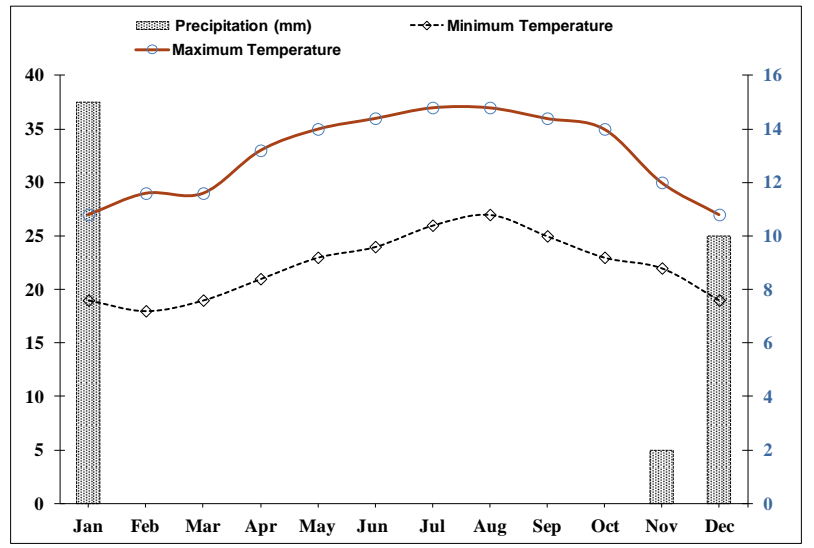

Fig.1. Climatic conditions of the experimentalsite during 201315 (Hada-Al Sham, Jeddah-Saudi Arabia)

The experiment consisted of treating plots with two types of BOR (BOR $\mathrm{EM}_{\mathrm{EM}}$ and $\left.\mathrm{BOR}_{\text {plain }}\right)$, each with 4 levels: 0 , 15,30 , and $45 \mathrm{t} \cdot \mathrm{ha}^{-1}$ ) in combination with humic acid (HA) (4 levels: $0,15,30$, and $45 \mathrm{~kg} \cdot \mathrm{ha}^{-1}$ ). Both BOR types were evaluated using a randomized complete block design with a split-plot arrangement (BOR as the main plot factor and HA as a sub-plot factor).

\section{Preparation of BOR}

BOR was prepared by composting cow manure (CM), poultry manure $(\mathrm{PM})$, and kitchen waste $(\mathrm{KW})$, in a ratio of 2:1:1 by volume for 3 months: one was without the addition of $\mathrm{EM}-1^{\circledR}$ to prepare the $\mathrm{BOR}_{\text {plain }}$, and other with the addition of EM- $1^{\circledR}$ to prepare the $\mathrm{BOR} \mathrm{EM}_{\mathrm{EM}} \mathrm{EM}-1^{\circledR}$ was provided by the EMRO (http://www.emrojapan.com) Saudi partner, Rashed Establishment for Trading and Agriculture (http://www.rashedagri.com.sa). The BOR EM was produced by activating theEM- $1^{\circledR}$ by adding a mixture of 1 part molasses and 20 parts water, and apply it to the BOR after 1 week, at a rate of $1 \mathrm{~L} \cdot \mathrm{t}^{-1} \mathrm{BOR}$.

\section{Agronomic practices and data collection}

The organic fertilizers (BOR and HA) were applied to the experimental field every year, two weeks prior to sowing. The crop was sown each year in the first week of October, and the $1^{\text {st }}$ harvest was carried out 45 days after sowing (DAS), while the subsequent 3 harvests were carried out at 1 month intervals. All other agronomic practices were carried out uniformly in all treatments.

To assess the effects of the treatments on the crop production, data on crop yield and mineral composition were compiled. Fresh forage and dry matter yields were determined according to the method described by Daur and Tatar (2013). Subsequently, the dry matter samples were analyzed for their mineral composition.

\section{Mineral Analysis}

Each year, the oven-dried samples from all cuts were combined separately according to treatments structure and powdered. The powdered samples were used for mineral analysis. Nitrogen content was determined according to Bremner (1996), using the Kjeldahl method. Phosphorus was determined colorimetrically following protocol described by Ryan et al. (2001), and all other elements were determined according to Bakhashwain et al. (2013), using Varian ICP-OES (Inductively Coupled PlasmaOptical Emission Spectroscopy).

\section{Statistical Analysis}

Data were analyzed using MSTATC software, following the procedure for RCBD with a split-plot arrangement, and a climatic graph was drawn using Microsoft Excel (Microsoft Corp., Redmond, WA, USA).

\section{RESULTS AND DISCUSSION}

Fresh (Table 2) and dry matter (Table 3) yields both varied significantly $(\mathrm{p}<0.05)$ among all treatments. However, their interactions were non-significant. Yield increased significantly with $\mathrm{BOR}\left(\mathrm{BOR}_{\text {plain }}\right.$ or $\left.\mathrm{BOR}_{\mathrm{EM}}\right)$ and HA treatment levels. Previous studies support our results, which indicate that organic manure has beneficial effects on the physical and chemical properties of soil, and supplies plants with important nutrients (Abusuwar and Daur, 2014; Ali et al., 2014, Ouni et al., 2014a). Moreover, humic acids improve soil structure and soil fertility, the metabolisms of soil microorganisms, and nutrient uptake. In addition, it enhances the water-holding capacity of the soil, leading to exceptional plant growth and micronutrient uptake (Ouni et al., 2014b; Plaza et al., 2015). 
Table 2. Fresh yield $\left(\mathrm{t} \cdot \mathrm{ha}^{-1}\right)$ of berseem under different levels and types of BOR, integrated with different levels of humic acid.

\begin{tabular}{|c|c|c|c|c|c|c|}
\hline \multirow{2}{*}{\multicolumn{2}{|c|}{ BOR Levels/BOR Types }} & \multicolumn{5}{|c|}{ Humic Acid Levels } \\
\hline & & $\mathbf{0}$ & 15 & 30 & 45 & MeansBor \\
\hline & & \multicolumn{4}{|c|}{ Interaction (BOR x Humic acid) } & \\
\hline \multirow{2}{*}{0} & BOR $_{\text {plain }}$ & 16.80 & 18.32 & 19.60 & 20.00 & $18.68^{d}$ \\
\hline & BOREM $_{\text {EM }}$ & 16.88 & 18.32 & 19.92 & 20.16 & $18.82^{\mathrm{cd}}$ \\
\hline \multirow{2}{*}{15} & $\mathbf{B O R}_{\text {plain }}$ & 19.64 & 19.20 & 19.76 & 20.40 & $19.75^{c}$ \\
\hline & BOREM $_{\text {EM }}$ & 20.44 & 20.96 & 20.40 & 21.20 & $20.75^{b}$ \\
\hline \multirow{2}{*}{30} & $\mathbf{B O R}_{\text {plain }}$ & 20.80 & 20.88 & 20.72 & 21.68 & $21.02^{\mathrm{ab}}$ \\
\hline & BOREM & 20.88 & 20.72 & 20.80 & 21.68 & $21.02^{\mathrm{ab}}$ \\
\hline \multirow{2}{*}{45} & BOR $_{\text {plain }}$ & 21.60 & 21.68 & 22.16 & 22.32 & $21.94^{\mathrm{ab}}$ \\
\hline & BOREM & 21.60 & 21.68 & 22.00 & 22.72 & $22.00^{a}$ \\
\hline \multicolumn{2}{|c|}{ MeanshA } & $19.83^{\mathrm{c}}$ & $20.22^{b}$ & $20.67^{b c}$ & $21.27^{\mathrm{a}}$ & \\
\hline
\end{tabular}

ANOVA Results: BOR $=$ Significant $p<0.05$; Humic acid Levels $=$ Significant $p<0.05$; BOR $x$ Humic acid $=$ nonsignificant

Mean values with different superscript letters differ significantly $(\mathrm{p}<0.05)$

$\mathrm{BOR}=$ Blend of Organic resources; $\mathrm{BOR}_{\text {plain }}=\mathrm{BOR}$ without EM.1; $\mathrm{BOR} \mathrm{EM}_{\mathrm{E}}=\mathrm{BOR}$ with EM.1; HA = Humic acid

Table 3. Dry matter yield $\left(\mathrm{t} \cdot \mathrm{ha}^{-1}\right)$ of berseem under different levels and types of BOR, integrated with different levels of humic acid.

\begin{tabular}{|c|c|c|c|c|c|c|}
\hline \multirow{2}{*}{\multicolumn{2}{|c|}{ BOR Levels/BOR Types }} & \multicolumn{5}{|c|}{ Humic Acid Levels } \\
\hline & & $\mathbf{0}$ & 15 & 30 & 45 & Meansbor \\
\hline & & \multicolumn{4}{|c|}{ Interaction (BOR x Humic acid) } & \\
\hline \multirow{2}{*}{0} & BOR $_{\text {plain }}$ & 5.50 & 6.05 & 6.46 & 6.60 & $6.15^{d}$ \\
\hline & BOREM $_{\text {EM }}$ & 5.54 & 6.07 & 6.57 & 6.65 & $6.21^{\mathrm{cd}}$ \\
\hline \multirow{2}{*}{15} & $\mathbf{B O R}_{\text {plain }}$ & 6.56 & 6.36 & 6.52 & 6.74 & $6.55^{\mathrm{c}}$ \\
\hline & BOREM $_{\text {EM }}$ & 6.76 & 6.64 & 6.73 & 7.00 & $6.78^{b c}$ \\
\hline \multirow{2}{*}{30} & BOR $_{\text {plain }}$ & 6.86 & 6.80 & 6.80 & 7.10 & $6.89^{\mathrm{bc}}$ \\
\hline & BOREM & 6.89 & 6.84 & 6.86 & 7.18 & $6.94^{\mathrm{b}}$ \\
\hline \multirow{2}{*}{45} & $\mathbf{B O R}_{\text {plain }}$ & 6.94 & 7.10 & 7.26 & 7.46 & $7.19^{\mathrm{ab}}$ \\
\hline & BOREM & 7.15 & 7.15 & 7.28 & 7.66 & $7.31^{\mathrm{a}}$ \\
\hline \multicolumn{2}{|c|}{ MeanSHA } & $6.53^{c}$ & $6.63^{b}$ & $6.81^{\mathrm{ab}}$ & $7.05^{a}$ & \\
\hline
\end{tabular}

ANOVA Results: BOR $=$ Significant $p<0.05$; Humic acid Levels $=$ Significant $p<0.05$; BOR $x$ Humic acid $=$ non-

significant

Mean values with different superscript letters differ significantly $(\mathrm{p}<0.05)$

$\mathrm{BOR}=$ Blend of Organic resources; $\mathrm{BOR}_{\text {plain }}=\mathrm{BOR}$ without EM.1; $\mathrm{BOR}_{\mathrm{EM}}=\mathrm{BOR}$ with EM.1; HA = Humic acid

Table 4 illustrates the statistically significant $(\mathrm{p}<$ 0.05) differences among all BOR and humic acid (HA) levels on soil nitrogen $(\mathrm{N})$ composition. Our findings are on par with those of Tahir et al. (2011) and Antoniadis et al. (2015), which indicate that nitrogen $(\mathrm{N})$, phosphorus $(\mathrm{P})$, and potassium $(\mathrm{K})$ uptake increased in response to augmentation of organic material and humic acid. However, the interaction between BOR and HA appeared to have a non-significant $(\mathrm{p}<0.05)$ effect on $\mathrm{N}$ composition. $\mathrm{N}$ composition increased with increasing levels of BOR and humic acid, but plant $\mathrm{N}$ content was higher when plants were treated with $\mathrm{BOR}_{\mathrm{EM}}$ than when

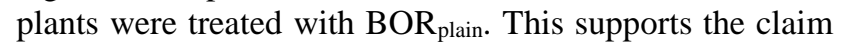
that EM.1 inoculation improves organic matter composting without nitrogen loss as in other methods of composting occurs (Himanen and Hänninen, 2009). Findings related to the function of EM.1 in composting have not been previously reported, because EM.1 has generally been used only for either waste degradation or fermentation. However, previous studies confirm that microorganisms play a primary role during the composting of organic material, with the aid of a multienzyme system. EM.1 includes anaerobic bacteria and some other microorganisms that produce unique multienzyme complexes, called cellulosomes. These multienzyme complexes are responsible for the rapid degradation of organic materials (Schwarz, 2001; Kato et al. 2004; Wilson, 2011)

The differences in phosphorus $(\mathrm{P})$ content (Table 5) were statistically non-significant $(\mathrm{p}<0.05)$ among all BOR and HA treatments. However, Cimrin and Yilmaz, (2006) reported that humic acid improves phosphorus availability. This could be because adequate phosphorus content was already present in the soil. The differences in the potassium $(\mathrm{K})$ content of berseem were also nonsignificant $(\mathrm{p}<0.05)$ among BOR levels, but varied significantly $(\mathrm{p}<0.05)$ among the humic acid levels (Table 6). Our results are comparable with those of Nikbakht et al. (2008), where the nitrogen $(\mathrm{N})$, potassium $(\mathrm{K})$, and magnesium $(\mathrm{Mg})$ composition of plants were significantly improved with the application of higher levels of HA. 
Table 4. Nitrogen composition $\left(\mathrm{mg} \cdot \mathrm{g}^{-1}\right)$ of berseem dry biomass under different levels and types of BOR, integrated with different levels of humic acid.

\begin{tabular}{|c|c|c|c|c|c|c|}
\hline \multirow{2}{*}{\multicolumn{2}{|c|}{ BOR Levels/BOR Types }} & \multicolumn{5}{|c|}{ Humic Acid Levels } \\
\hline & & $\mathbf{0}$ & 15 & 30 & 45 & MeansBor \\
\hline \multicolumn{7}{|c|}{ Interaction (BOR x Humic acid) } \\
\hline \multirow{2}{*}{0} & $\mathbf{B O R}_{\text {plain }}$ & 31.0 & 36.2 & 38.1 & 40.0 & $36.3^{c}$ \\
\hline & BOREM & 31.2 & 36.6 & 38.5 & 40.3 & $36.7^{\mathrm{bc}}$ \\
\hline \multirow{2}{*}{15} & $\mathbf{B O R}_{\text {plain }}$ & 38.1 & 38.0 & 40.1 & 40.0 & $39.1^{b}$ \\
\hline & BOREM $_{\text {EM }}$ & 39.2 & 40.3 & 40.4 & 40.4 & $40.1^{b}$ \\
\hline \multirow{2}{*}{30} & BOR $_{\text {plain }}$ & 39.4 & 40.4 & 40.2 & 40.4 & $40.1^{b}$ \\
\hline & BOREM $_{\text {EM }}$ & 41.3 & 42.3 & 42.3 & 42.3 & $42.1^{\mathrm{ab}}$ \\
\hline \multirow{2}{*}{45} & BOR $_{\text {plain }}$ & 41.3 & 41.2 & 41.4 & 41.6 & $41.4^{\mathrm{ab}}$ \\
\hline & BOREM & 42.2 & 43.3 & 43.2 & 43.2 & $43.0^{\mathrm{a}}$ \\
\hline \multicolumn{2}{|c|}{ MeanSHA } & $38.0^{b}$ & $39.8^{\mathrm{ab}}$ & $40.5^{\mathrm{ab}}$ & $41.0^{a}$ & \\
\hline
\end{tabular}

ANOVA Results: BOR = Significant $p<0.05$; Humic acid Levels $=$ Significant $p<0.05$; BOR $x$ Humic acid $=$ nonsignificant

Mean values with different superscript letters differ significantly $(\mathrm{p}<0.05)$

$\mathrm{BOR}=$ Blend of Organic resources; $\mathrm{BOR}_{\text {plain }}=\mathrm{BOR}$ without EM.1; $\mathrm{BOR}_{\mathrm{EM}}=\mathrm{BOR}$ with EM. $1 ; \mathrm{HA}=$ Humic acid

Table 5. Phosphorus composition $\left(\mathrm{mg} \cdot \mathrm{g}^{-1}\right)$ of berseem dry biomass under different levels and types of BOR, integrated with different levels of humic acid.

\begin{tabular}{|c|c|c|c|c|c|c|}
\hline \multirow{2}{*}{\multicolumn{2}{|c|}{ BOR Levels/BOR Types }} & \multicolumn{5}{|c|}{ Humic Acid Levels } \\
\hline & & $\mathbf{0}$ & 15 & 30 & 45 & Meansbor \\
\hline \multicolumn{7}{|c|}{ Interaction (BOR x Humic acid) } \\
\hline \multirow{2}{*}{0} & $\mathbf{B O R}_{\text {plain }}$ & 3.3 & 3.6 & 3.4 & 3.3 & 3.4 \\
\hline & BOREM $_{\text {EM }}$ & 4.0 & 3.4 & 3.4 & 3.8 & 3.7 \\
\hline \multirow{2}{*}{15} & BOR $_{\text {plain }}$ & 3.4 & 3.5 & 3.6 & 3.3 & 3.5 \\
\hline & BOREM & 3.8 & 3.3 & 3.3 & 3.4 & 3.5 \\
\hline \multirow{2}{*}{30} & BOR $_{\text {plain }}$ & 3.4 & 3.5 & 3.4 & 3.5 & 3.5 \\
\hline & BOREM & 3.6 & 3.6 & 3.4 & 3.4 & 3.5 \\
\hline \multirow{2}{*}{45} & BOR plain & 3.3 & 3.3 & 3.6 & 3.3 & 3.4 \\
\hline & BOREM & 4.0 & 3.4 & 3.3 & 3.6 & 3.6 \\
\hline \multicolumn{2}{|c|}{ MeanSHA } & 3.6 & 3.5 & 3.4 & 3.5 & \\
\hline
\end{tabular}

ANOVA Results: BOR = non-significant; Humic acid Levels = non-significant; BOR x Humic acid = non-significant

Mean values with different superscript letters differ significantly $(\mathrm{p}<0.05)$

$\mathrm{BOR}=$ Blend of Organic resources; $\mathrm{BOR}_{\text {plain }}=\mathrm{BOR}$ without EM.1; BOR $\mathrm{EM}=\mathrm{BOR}$ with EM.1; HA $=$ Humic acid

Table 6. Potassium composition $\left(\mathrm{mg} \cdot \mathrm{g}^{-1}\right)$ of berseem dry biomass under different levels and types of BOR, integrated with different levels of humic acid.

\begin{tabular}{|c|c|c|c|c|c|c|}
\hline \multirow{2}{*}{\multicolumn{2}{|c|}{ BOR Levels/BOR Types }} & \multicolumn{5}{|c|}{ Humic Acid Levels } \\
\hline & & $\mathbf{0}$ & 15 & 30 & 45 & MeansBor \\
\hline \multicolumn{7}{|c|}{ Interaction (BOR x Humic acid) } \\
\hline \multirow{2}{*}{0} & BOR plain & 2.2 & 2.5 & 2.4 & 2.7 & 2.5 \\
\hline & BOREM & 2.2 & 2.7 & 2.8 & 2.7 & 2.6 \\
\hline \multirow{2}{*}{15} & BOR $_{\text {plain }}$ & 2.2 & 2.5 & 2.7 & 2.7 & 2.5 \\
\hline & BOREM & 2.2 & 2.5 & 2.6 & 2.8 & 2.5 \\
\hline \multirow{2}{*}{30} & $\mathbf{B O R}_{\text {plain }}$ & 2.4 & 2.4 & 2.7 & 2.7 & 2.6 \\
\hline & BOREM $_{\mathbf{E M}}$ & 2.4 & 2.5 & 2.6 & 2.5 & 2.5 \\
\hline \multirow{2}{*}{45} & $\mathbf{B O R}_{\text {plain }}$ & 2.4 & 2.4 & 2.6 & 2.8 & 2.6 \\
\hline & BOREM & 2.6 & 2.6 & 2.8 & 2.8 & 2.7 \\
\hline \multicolumn{2}{|c|}{ MeanSHA } & $2.3^{a}$ & $2.5^{\mathrm{ab}}$ & $2.7^{b}$ & $2.7^{b}$ & \\
\hline
\end{tabular}

ANOVA Results: BOR = non-significant; Humic acid Levels $=$ Significant $\mathrm{p}<0.05$; BOR x Humic acid $=$ nonsignificant

Mean values with different superscript letters differ significantly $(\mathrm{p}<0.05)$

$\mathrm{BOR}=$ Blend of Organic resources; $\mathrm{BOR}_{\text {plain }}=\mathrm{BOR}$ without EM.1; BOR $\mathrm{EM}=$ BOR with EM.1; HA = Humic acid 
Calcium $(\mathrm{Ca})$ content was statistically similar in all BOR and HA levels (Table 7). The probable reason for this is that the soil in Saudi Arabia has high calcium content, and thus it is not a limiting factor (Al-Juhaimi et al., 2014). Magnesium (Mg) content (Table 8) varied significantly ( $\mathrm{p}<0.05$ ) across humic acid levels. This could be because humic acid itself contains reasonably high concentrations of $\mathrm{Mg}$. The results of Nikbakht et al.(2008) and Ananthi and Vanangamudi (2014) support our study results that HA improves $\mathrm{Mg}$ uptake.

Table 7. Calcium composition $\left(\mathrm{mg} \cdot \mathrm{g}^{-1}\right)$ of berseem dry biomass under different levels and types of BOR, integrated with different levels of humic acid.

\begin{tabular}{|c|c|c|c|c|c|c|}
\hline \multirow{2}{*}{\multicolumn{2}{|c|}{ BOR Levels/BOR Types }} & \multicolumn{5}{|c|}{ Humic Acid Levels } \\
\hline & & $\mathbf{0}$ & 15 & 30 & 45 & MeanSBoR \\
\hline & & \multicolumn{4}{|c|}{ Interaction (BOR x Humic acid) } & \\
\hline \multirow{2}{*}{0} & BOR plain & 1.7 & 1.9 & 1.9 & 1.8 & 1.8 \\
\hline & BOREM & 1.6 & 1.6 & 1.7 & 1.7 & 1.7 \\
\hline \multirow{2}{*}{15} & $\mathbf{B O R}_{\text {plain }}$ & 1.7 & 1.6 & 1.7 & 1.6 & 1.7 \\
\hline & BOREM $_{\text {EM }}$ & 1.7 & 1.7 & 1.7 & 1.6 & 1.7 \\
\hline \multirow{2}{*}{30} & $\mathbf{B O R}_{\text {plain }}$ & 1.9 & 1.9 & 1.8 & 1.7 & 1.8 \\
\hline & BOREM $_{\text {EM }}$ & 1.7 & 1.7 & 1.7 & 1.7 & 1.7 \\
\hline \multirow{2}{*}{45} & $\mathbf{B O R}_{\text {plain }}$ & 1.9 & 1.7 & 1.8 & 1.9 & 1.8 \\
\hline & BOREM $_{\text {EM }}$ & 1.7 & 1.9 & 1.8 & 1.7 & 1.8 \\
\hline \multicolumn{2}{|c|}{ MeanSHA } & 1.7 & 1.8 & 1.8 & 1.7 & \\
\hline
\end{tabular}

ANOVA Results: BOR = non-significant; Humic acid Levels = non-significant; BOR x Humic acid = non-significant Mean values with different superscript letters differ significantly $(\mathrm{p}<0.05)$

$\mathrm{BOR}=$ Blend of Organic resources; $\mathrm{BOR}_{\text {plain }}=\mathrm{BOR}$ without EM.1; $\mathrm{BOR}_{\mathrm{EM}}=\mathrm{BOR}$ with EM.1; HA = Humic acid

Table 8. Magnesium composition $\left(\mathrm{mg} \cdot \mathrm{g}^{-1}\right)$ of berseem dry biomass under different levels and types of BOR, integrated with different levels of humic acid.

\begin{tabular}{|c|c|c|c|c|c|c|}
\hline \multirow{2}{*}{\multicolumn{2}{|c|}{ BOR Levels/BOR Types }} & \multicolumn{5}{|c|}{ Humic Acid Levels } \\
\hline & & $\mathbf{0}$ & 15 & 30 & 45 & Means $_{\text {воR }}$ \\
\hline & & \multicolumn{4}{|c|}{ Interaction (BOR x Humic acid) } & \\
\hline \multirow{2}{*}{0} & BOR $_{\text {plain }}$ & 2.0 & 2.3 & 2.4 & 2.4 & 2.3 \\
\hline & BOREM & 2.1 & 2.3 & 2.3 & 2.4 & 2.3 \\
\hline \multirow{2}{*}{15} & $\mathbf{B O R}_{\text {plain }}$ & 2.1 & 2.2 & 2.2 & 2.5 & 2.3 \\
\hline & BOREM & 2.2 & 2.2 & 2.4 & 2.5 & 2.3 \\
\hline \multirow{2}{*}{30} & $\mathbf{B O R}_{\text {plain }}$ & 2.2 & 2.3 & 2.4 & 2.4 & 2.3 \\
\hline & BOREM & 2.2 & 2.3 & 2.4 & 2.5 & 2.4 \\
\hline \multirow{2}{*}{45} & BOR $_{\text {plain }}$ & 2.2 & 2.3 & 2.4 & 2.4 & 2.3 \\
\hline & BOREM $_{\text {EM }}$ & 2.2 & 2.3 & 2.4 & 2.5 & 2.4 \\
\hline \multicolumn{2}{|c|}{ Means $_{\mathrm{HA}}$} & $2.2^{\mathrm{a}}$ & $2.3^{a b}$ & $2.4^{\mathrm{ab}}$ & $2.5^{b}$ & \\
\hline
\end{tabular}

ANOVA Results: BOR = non-significant; Humic acid Levels $=$ Significant $\mathrm{p}<0.05$; BOR $\mathrm{x}$ Humic acid $=$ non-significant

Mean values with different superscript letters differ significantly $(\mathrm{p}<0.05)$

$\mathrm{BOR}=$ Blend of Organic resources; $\mathrm{BOR}_{\text {plain }}=\mathrm{BOR}$ without EM.1; BOR $\mathrm{EM}=\mathrm{BOR}$ with EM.1; HA = Humic acid

\section{CONCLUSION AND RECOMMENDATION}

In conclusion, EM.1 inoculation increases the fertilizer value of compost. Additionally, this study confirmed that increasing levels of organic manure and HA enhance nutrient uptake and increase crop yield. Further study is recommended, in order to investigate the effects of EM.1 and HA on biochemical reactions and the ultra-structures of cells.

\section{ACKNOWLEDGEMENT}

This project was funded by the Deanship of Scientific Research (DSR), King Abdulaziz University, Jeddah, under Grant No.(219-155-1434). The authors, therefore, acknowledges with thanks DSR technical and financial support.

\section{LITERATURE CITED}

Abusuwar, A and I. Daur. 2014. Effect of cow and poultry manures on yield, quality and seed production of two alfalfa cultivars under saline arid environment. J. Food, Agric., and Environment. 12(2):747-751.

Ali, A.H., M.R. Shafeek, R. A. Mahmoud, and M. El- Desuki. 2014. Effect of various levels of organic fertilizer and humic acid on the growth and roots quality of turnip plants (Brassica rapa). Current Science International, 3(1): 7-14.

Al-Juhaimi, F.Y., S.H. Hamad, I.S. Al-Ahaideb, M.M. Al-Otaibi, M.M. El-Garawany. 2014. Effects of Fertilization with Liquid Extracts of Biogas Residues on the Growth and 
Forage Yield of Alfalfa (Medicago sativa L.) under Arid Zone Conditions. Pakistan Journal of Botany, 46 (2): 471 475

Ananthi, K. and M. Vanangamudi. 2014. Foliar spray of humic acid with growth regulators in nutrient content and yield of greengram [Vigna radiata (L.) Wilczek]. Legume Research, 37(4): 359-362

Antoniadis, V., S.D. Koutroubas and S. Fotiadis. 2015. Nitrogen, Phosphorus, and Potassium Availability in Manure- and Sewage Sludge-Applied Soil. Communications in Soil Science and Plant Analysis, 46(3): 393-404.

Bakhashwain, A.A., I. Daur, R.A.A. Abohassan and F.S. ElNakhlawy. 2013. Response of genetically divergent pearl millet [Pennisetum glaucum (L.) R. Br.] Varieties to different organo-mineral fertility management. Pak. J. Bot., 45(5): 1657-1661.

Bremner, J.M. 1996. Nitrogen-total. In: Methods of Soil Analysis. (Ed.): D.L. Sparks, Part 3. Am. Soc. Agron., 37: 1085-1122.

Cimrin, K.M. and I. Yilmaz. 2006. Humic acid applications to lettuce do not improve yield but do improve phosphorus availability. Acta Agriculturae Scandinavica, Section B Soil \& Plant Science. 55, 58-63.

Daur, I. and O. Tatar. 2013. Effects of gypsum and brassinolide on soil properties, and berseem (Trifolium alexandrinum L.) growth, yield and chemical composition grown on saline soil. Legume Res., 36 (4): 306 - 311.

Gomiero, T., D. Pimentel and M.G. Paoletti. 2011. Environmental impact of different agricultural management practices: conventional vs. organic agriculture. Critical Reviews in Plant Sciences, 30: 95-124.

Himanen, M. and K. Hänninen. 2009. "Effect of Commercial Mineral-Based Additives on Composting and Compost Quality." Waste Management 29: 2265-2273

Humintech. 2012. Is it possible to replace organic manure with Humic acid? http://www.humintech.com (accessed 03 Jan, 2013).
Kato, S., S. Haruta, Z.J. Cui, M. Ishii and Y. Igarashi. 2004. Effective cellulose degradation by a mixed-culture system composed of a cellulolytic Clostridium and aerobic noncellulolytic bacteria. FEMS Microbiology Ecology, 51: 133 -142 .

Nikbakht, A., M. Kafi, M. Babalar, Y.P. Xia, A. Luo and N. Etemadi. 2008. Effect of Humic Acid on Plant Growth, Nutrient Uptake, and Postharvest Life of Gerbera. Journal of Plant Nutrition, 31(12): 2155-2167.

Ouni, Y., A. Albacete, E. Cantero, A. Lakhdar, C. Abdelly, F. Pérez-Alfocea and Z. Barhoumi. 2014a. Influence of municipal solid waste (MSW) compost on hormonal status and biomass partitioning in two forage species growing under saline soil conditions. Ecological Engineering, 64: $142-150$.

Ouni, Y., T. Ghnaya, F. Montemurro, C. Abdelly and A. Lakhdar. 2014b. The role of humic substances in mitigating the harmful effects of soil salinity and improve plant productivity. International Journal of Plant Production, 8(3): 353-374.

Plaza, I., A. Ontiveros-Ortega, J. Calero and V. Aranda. 2015. Implication of zeta potential and surface free energy in the description of agricultural soil quality: Effect of different cations and humic acids on degraded soils. Soil \& Tillage Research, 146: 148-158

Ryan, J., G. Estefan, and A. Rashid. 2001. Soil and Plant Analysis Laboratory Manual, 2nd ed. Aleppo, Syria: International Center for Agricultural Research in the Dry Areas and the National Agricultural Research Center.

Schwarz, W. 2001. The cellulosome and cellulose degradation by anaerobic bacteria. Applied Microbiology and Biotechnology, 56: 634-649.

Tahir M.M., M. Khurshid, M.Z. Khan, M.K. Abbasi and M.H. Kazmi. 2011. Lignite-derived humic acid effect on growth of wheat plants in different soils, Pedosphere. 21(1): 124-131.

Wilson, D.B. 2011. Microbial diversity of cellulose hydrolysis. Current Opinion in Microbiology, 14(3): 259-263. 